\title{
Development of herbicide-tolerant irrigated rice cultivars
}

\author{
Paulo Hideo Nakano Rangel(1), Francisco Pereira Moura Neto(1), Paulo Ricardo Reis Fagundes ${ }^{(2)}$, \\ Ariano Martins de Magalhães Junior( ${ }^{(2)}$, Orlando Peixoto de Morais ${ }^{(1)}$, Andréa Branco Schmidt(3), \\ João Antônio Mendonça(1), Carlos Martins Santiago(1), Priscila Nascimento Rangel ${ }^{(1)}$, \\ Veridiano dos Anjos Cutrim ${ }^{(1)}$ and Márcio Elias Ferreira(4)
}

\begin{abstract}
(1)Embrapa Arroz e Feijão, Caixa Postal 179, CEP 75375-000 Santo Antônio de Goiás, GO, Brazil. E-mail: phrangel@cnpaf.embrapa.br, fpmn@cnpaf.embrapa.br, peixoto@cnpaf.embrapa.br, joaoam@cnpaf.embrapa.br, carlosm@cnpaf.embrapa.br, rangelpriscila@hotmail.com, cutrim@cnpaf.embrapa.br (2)Embrapa Clima Temperado, Estação Experimental de Terras Baixas, Caixa Postal 403, 96001-970 Capão do Leão, RS, Brazil. E-mail: fagundes@cpact.embrapa.br ${ }^{(3)}$ Universidade Federal de Santa Catarina, Campus Reitor João David Ferreira Lima, Bairro Trindade, CEP 88040-970 Florianópolis, SC, Brazil. E-mail: andreaschm@gmail.com ${ }^{(4)}$ Embrapa Recursos Genéticos e Biotecnologia, Caixa Postal 02372, CEP 70770-917 Brasília, DF, Brazil. E-mail: ferreira@cenargen.embrapa.br
\end{abstract}

\begin{abstract}
The objective of this work was to develop new irrigated rice lines tolerant to imidazolinone herbicides. The backcross breeding procedure was used to transfer the imidazolinone tolerance allele from mutant 93AS3510 to the recurrent parents 'BRS 7 Taim' and 'BRS Pelota'. Individual herbicide-tolerant plants were selected in each generation, for three backcrossings $\left(\mathrm{RC}_{1}\right.$ to $\left.\mathrm{RC}_{3}\right)$, followed by three selfing generations $\left(\mathrm{RC}_{3} \mathrm{~F}_{1}\right.$ to $\left.\mathrm{RC}_{3} \mathrm{~F}_{3}\right)$. The best four $\mathrm{RC}_{3} \mathrm{~F}_{3}$ lines for agronomic traits were genotyped with 44 microsatellite markers. The observed conversion index of the new imidazolinone-tolerant lines varied from 91.86 to $97.67 \%$. Pairwise genetic distance analysis between these lines and 22 accessions from the Embrapa's Rice Germplasm Bank clustered the new lines with their respective recurrent parents, but not with 'IRGA 417', which was originally used as recurrent parent to derive IRGA $422 \mathrm{CL}$, the only imidazolinone-tolerant irrigated rice cultivar recommended for cultivation in Brazil. Therefore, these lines represent new options of genetically diverse imidazolinone-tolerant rice accessions. Lines CNA10756 ('BRS Sinuelo CL') and CNA10757 will be released for cultivation in the Clearfield irrigated rice production system in Rio Grande do Sul, Brazil.
\end{abstract}

Index terms: Oryza sativa, backcrossing, Clearfield rice, microsatellites, red rice.

\section{Desenvolvimento de cultivares de arroz irrigado tolerantes a herbicida}

Resumo - O objetivo deste trabalho foi desenvolver novas linhagens de arroz irrigado tolerantes ao herbicida imidazolinona. $\mathrm{O}$ método de retrocruzamento foi usado para transferir o alelo de tolerância à imidazolinona do mutante 93AS3510 para os genitores recorrentes 'BRS 7 Taim' e 'BRS Pelota'. Indivíduos tolerantes ao

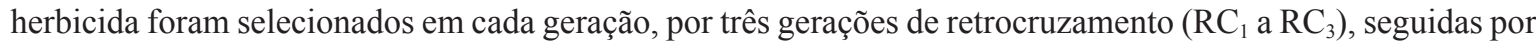
três gerações de autofecundação $\left(\mathrm{RC}_{3} \mathrm{~F}_{1}\right.$ a $\left.\mathrm{RC}_{3} \mathrm{~F}_{3}\right)$. As quatro melhores linhagens $\mathrm{RC}_{3} \mathrm{~F}_{3}$ quanto às características agronômicas foram genotipadas com 44 marcadores microssatélites. $\mathrm{O}$ índice de conversão observado nas novas linhagens tolerantes à imidazolinona variou de 91,86 a 97,67\%. A análise de distância genética par-a-par, entre estas linhagens e 22 acessos do banco de germoplasma de arroz da Embrapa, agrupou-as com os seus respectivos genitores recorrentes, mas não com 'IRGA 417', que foi originalmente usada como genitor para derivar a IRGA 422 CL, única cultivar tolerante ao herbicida imidazolinona recomendada para cultivo no Brasil. Portanto, estas linhagens representam novas opções de acessos geneticamente diversos de arroz irrigado com tolerância ao herbicida imidazolinona. As linhagens CNA10756 ('BRS Sinuelo' CL) e CNA10757 serão lançadas para cultivo no sistema de produção "Clearfield" no Rio Grande do Sul, Brasil.

Termos para indexação: Oryza sativa, retrocruzamento, arroz Clearfield, microssatélites, arroz-vermelho.

\section{Introduction}

The occurrence of weeds in irrigated rice fields, such as red rice, creates serious limitations for increasing grain yield, particularly in the state of Rio Grande do Sul, Brazil. This state alone is responsible for nearly
$60 \%$ of the rice produced in Brazil (Companhia Nacional do Abastecimento, 2008). Red rice is generally classified as $O$. sativa L. (Vaugham et al., 2001). Since rice and red rice are both variations of the same species, with a great degree of physiological similarity, it has been difficult to control this weed in

Pesq. agropec. bras., Brasília, v.45, n.7, p.701-708, jul. 2010 
the field. Red rice infestation is a challenge for rice production in Brazil and many other countries. Until the beginning of this decade, there was no herbicide available which could control red rice in cultivated rice fields (Webster \& Masson, 2001).

Some of the enzymes involved in the synthesis of amino acids in plants have been potential sites for finding molecules with herbicidal effect. Among the ones that stand out, ALS enzyme, or acetolactate synthase (EC 4.1.3.18), also known as AHAS (acetohydroxyacid synthase), acts on the biosynthesis of branched-chain amino acids in plants. The deactivation of the ALS enzyme causes plant annihilation. The ALS enzyme has been the target of many different families of herbicides, such as imidazolinones, sulfonylureas, triazolopyrimidines, pyrimidinyl-hiobenzoates and sulfonyl-amino-carbonyl-triazolinones(Mallory-Smith \& Retzinger Junior, 2003), the last one not yet commercialized in Brazil.

Imidazolinones include the active groups imazapyr, imazapic, imazethapyr, imazamox, imazamethabenz and imazaquin. These herbicides, even in low rates, have a toxic effect on dicotyledon species and on grasses and cyperaceous plants. Additionally, they have a low level of toxicity to mammals and little environmental impact (De Block et al., 1987). Some natural or induced mutations in the ALS gene cause tolerance to imidazolinone herbicides. These mutants are of great commercial value. In rice, two mutations of guanine to adenine (G/A) in the positions $1,880 \mathrm{pb}$ and $1,883 \mathrm{pb}$ of the ALS gene cause substitutions of amino acids serine to asparagine and glicine to glutamic acid, which prevent the binding of imidazolinone molecules to the mutant ALS enzyme, causing tolerance (Tan et al., 2005).

The introgression of herbicide-resistant genes has been carried out by classical methods of plant breeding, such as backcrossing, with no need to employ transgenic constructions through genetic engineering. Tolerance of imidazolinone in rice is based on lines derived from the cultivars AS3510 and Cypress treated with ethyl methanesulfonate (Croughan, 1996). This effort has lead to the identification of the mutant lines 93AS3510 - derived from the AS3510 cultivar - and PWC16, PWC23, CMC29, CMC31, WDC33, WDC37 and WDC38 - derived from the Cypress cultivar -, which provide tolerance to herbicides that inhibit the activity of the ALS enzyme. Four imidazolinone-tolerant cultivars derived from such lines were commercialized in the U.S. between 2001 and 2003 (Webster \& Masson, 2001; Gealy et al., 2003).

In Brazil, a backcross program was developed to obtain the cultivar IRGA $422 \mathrm{CL}$, derived from a cross between the mutant line 93AS3510 and the cultivar IRGA 417 (Sociedade Sul-Brasileira de Arroz Irrigado, 2007). Although it has been recently released, IRGA $422 \mathrm{CL}$ is already one of the most widely planted rice cultivars in the state of Rio Grande do Sul. Other cultivars tolerant to imidazolinones, preferably derived from a pedigree that is genetically distant from IRGA 422 CL, should be developed to minimize genetic vulnerability risks. The genetic base of rice breeding programs in Brazil is narrow and should be widened in order to diminish such risks (Rangel et al., 1996).

Microsatellite markers stand out among the class of molecular markers that are most widely used in breeding programs. Microsatellite analysis has been successfully used on genetic identity and paternity tests, phylogenetic analysis, genetic mapping, germplasm evaluation, marker-assisted selection, among other applications (Ferreira \& Grattapaglia, 1996). In backcrossing programs, microsatellites have been efficiently used to infer the level of genetic conversion of backcross lines to the genetic background of the recurrent parent.

The objective of this study was to develop new imidazolinone-tolerant lines of irrigated rice, to estimate the conversion level of the new lines to the genome of the recurrent parent, and to estimate the genetic distance between the herbicide-tolerant lines and other representative accessions of rice germplasm.

\section{Materials and Methods}

The development of new imidazolinone-tolerant lines of irrigated rice by Embrapa's breeding program began in November 2000 and was carried out at the field station of Embrapa Arroz e Feijão, in Santo Antônio de Goiás, GO, through backcrossing breeding method. The recurrent parents were the commercial irrigated rice cultivars BRS 7 Taim and BRS Pelota. The mutant line 93AS3510 was used as donor of the herbicide tolerance allele.

Three backcrossings were carried out $\left(\mathrm{RC}_{1}\right.$ to $\left.\mathrm{RC}_{3}\right)$, followed by three selfing generations $\left(\mathrm{RC}_{3} \mathrm{~F}_{1}\right.$ to $\left.\mathrm{RC}_{3} \mathrm{~F}_{3}\right)$. 
The seeds from the segregating generations $\mathrm{RC}_{1}$ to $\mathrm{RC}_{3} \mathrm{~F}_{3}$ were planted in plastic trays in greenhouse conditions. Twenty days after the emergency stage, the imidazolinone herbicide, commercial product Only (Imazethapyr $75 \mathrm{~g} \mathrm{~L}^{-1}+$ Imazapic $25 \mathrm{~g} \mathrm{~L}^{-1}$ ), (BASF, Guaratinguetá, Brazil), at $1.8 \mathrm{~L} \mathrm{ha}^{-1}$, plus surfactant Dash at $0.5 \%$ v/v(BASF, Guaratinguetá, Brazil) were sprayed on the plants. Ten days after the application, tolerant plants were identified and transplanted into pots. Individualized backcrossing to the respective recurrent parents was carried out at flowering. Progeny tests were developed on the $\mathrm{RC}_{3} \mathrm{~F}_{3}$ generation, when the homozygote lines were selected for the herbicide-tolerance allele. After preliminary evaluations in a number of different environments in the state of Rio Grande do Sul, six new Clearfield lines were selected, three of them derived from the cultivar BRS 7 Taim (CNA10754, CNA10755 and CNA10756) and the other three from the cultivar BRS Pelota (CNA10757, CNA10758 and CNA10759).

These six new lines, the herbicide-tolerant cultivar IRGA $422 \mathrm{CL}$ and the recurrent parents (BRS 7 Taim and BRS Pelota) were evaluated in agronomic trials for two consecutive years in seven municipalities of the state of Rio Grande do Sul: Alegrete, Uruguaiana, Agudo, Cachoeira do Sul, Capão do Leão, Arroio Grande and Santa Vitória do Palmar. The trials were done during the 2005/2006 and 2006/2007 crop seasons. A randomized complete block design was used, with four replicates. Each plot consisted of four 5-m long rows, in 2005/2006, and by four 8-m long rows in 2006/2007. Twenty days after the emergency stage, an application of the commercial product Only was done with the recommended rate of $1.0 \mathrm{~L} \mathrm{ha}^{-1}$, plus surfactant Dash at $0.5 \% \mathrm{v} / \mathrm{v}$. The weed control on plots of the parental cultivars, in each block, was carried out by manual roguing.

The parameters evaluated in the field were: days to flowering (average number of days between plant emergency and flowering), plant height $(\mathrm{cm})$, grain yield $\left(\mathrm{kg} \mathrm{ha}^{-1}\right)$, the incidence of brown spot disease (caused by a complex of pathogens) and narrow brown leaf spot (Sphaerulian oryzae K. Hara), according to Manual de métodos de pesquisa em arroz, (1977). Amilose content, gelatinization temperature, white center, cooking quality and grain texture data were evaluated in the grain quality laboratory at Embrapa
Arroz e Feijão, according to the protocols established by the International Center for Tropical Agriculture (Jennings et al., 1981).

Average grain yield data were submitted to individual and group analysis of variance considering years and location as random factors and the effects of treatments as fixed factors. The hypothesis of a null treatment effect was analyzed with $\mathrm{F}$ test, in accordance with Satterthwaite (1946). Treatment means were compared by Dunnet's test (Dunnet, 1955, 1964), at $5 \%$ probability.

The four most promising herbicide-tolerant lines (CNA10754, CNA10756, CNA10757 and CNA10758), the parental lines (BRS 7 Taim and BRS Pelota), and other 20 accessions from the Rice Germplasm Bank maintained by Embrapa Recursos Genéticos e Biotecnologia were genotyped with a battery of microsatellite markers used in rice. The data was used to characterize the genetic identity of each accession, by identifying its marker multiloci profile, and to estimate the pairwise genetic distance between accessions.

Twenty-six rice accessions, representing the indica and japonica subspecies, were genotyped using microsatellite markers: Amaroo, BG90-2, Bico Ganga, Chorinho, CNAi 9930, Colombia 1, BRSMG Curinga, Diamante, Farroupilha, Formoso, IRGA 417, Nipponbare, Oryzica Llanos 4, Oryzica Llanos 5, Oryzica 1, BRS Primavera, Puteca, Rantulasi, Zenith, BRS 7 Taim, 93AS3510, CNA 10757, CNA 10758, BRS Pelota, CNA 10754, CNA10756. The genomic DNA of each accession was extracted from a bulk of leaves of 20 rice seedlings, which were germinated in a growth chamber. A standard CTAB protocol was used (Doyle \& Doyle, 1990), with a few modifications. The grinding up of approximately $150 \mathrm{mg}$ of plant material was done on a FastPrep BIO101 homogeneizer with the CTAB cationic detergent (cationic hexadecyl trimethyl ammonium bromide). The making process of this suspension, both soluble and homogenized, was carried out in water bath at $60^{\circ} \mathrm{C}$ during 30 to $50 \mathrm{~min}$ and, immediately afterward, an organic solvent was added to the suspension (chloroform/isoamilic alcohol 24:1, v/v). The organic and aqueous phases were separated by centrifugation with the addition of isopropyl alcohol to the aqueous phase, in order to precipitate the nucleic acids. Two separate additions of $70 \%$ alcohol were applied for hydration and cleaning of the precipitate. The resuspension of the precipitate was performed in a tris-EDTA buffer containing 
RNAse to break down the RNA and isolate the genomic DNA. The DNA quantification was carried out in $1 \%$ agarose gel containing ethidium bromide $\left(0.15 \mu \mathrm{g} \mathrm{mL}^{-1}\right)$ (Sambrook et al., 1989), and the band intensity was compared with samples of DNA dilutions with known concentrations. The DNA was diluted to a final concentration of $2 n g \mu \mathrm{L}^{-1}$ for polymerase chain reaction (PCR) analysis.
Eight multiplex panels of microsatellite markers of rice were used. Each multiplex panel has the capacity of simultaneous amplification of alleles in different loci through a single polymerase chain reaction. Two pentaplex, four hexaplex and two heptaplex panels, all of them with a common locus marker (RM6810), and an additional triplex panel, totalling 44 microsatellite loci, were used in the analysis (Pessoa-Filho et al., 2007; Schmidt, 2009) (Table 1). The cultivar Nipponbare,

Table 1. Rice microsatellite markers used for genotyping Oryza sativa indica, O. sativa japonica rice accessions and the new imidazolinone-tolerant rice lines.

\begin{tabular}{|c|c|c|c|c|c|}
\hline Marker & Physical map site $(\mathrm{pb})^{(1)}$ & Fluorochrome & Chromosome & Motif & $\mathrm{T}\left({ }^{\circ} \mathrm{C}\right)$ \\
\hline RM5359 & 7.178 .539 & hex & 1 & $\mathrm{TC}$ & 50 \\
\hline RM3412 & 11.566 .961 & 6-fam & 1 & $\mathrm{CT}$ & 55 \\
\hline RM7405 & 21.899 .261 & ned & 1 & GATG & 55 \\
\hline RM7124 & 24.386 .986 & 6-fam & 1 & ATAA & 55 \\
\hline RM7215 & 4.790 .692 & 6-fam & 2 & ATAG & 55 \\
\hline RM300 & 13.190 .528 & ned & 2 & GTT & 55 \\
\hline RM263 & 25.865 .334 & 6-fam & 2 & $\mathrm{CT}$ & 55 \\
\hline RM475 & 20.398 .688 & ned & 2 & TATC & 55 \\
\hline RM22 & 1.500 .298 & ned & 3 & GA & 55 \\
\hline RM1164 & 14.694 .597 & hex & 3 & $\mathrm{AG}$ & 55 \\
\hline RM7431 & 19.324 .752 & ned & 3 & GTAC & 55 \\
\hline RM422 & 33.655 .206 & hex & 3 & $A G$ & 55 \\
\hline OG44 & 34.218 .136 & 6-fam & 3 & $(\mathrm{CT})(\mathrm{CT})(\mathrm{GT})(\mathrm{GC})$ & 56 \\
\hline RM335 & 679.893 & 6-fam & 4 & CTT & 55 \\
\hline RM307 & $-(2)$ & ned & 4 & $(\mathrm{AT})(\mathrm{GT})$ & 55 \\
\hline RM153 & 167.824 & 6-fam & 5 & GAA & 55 \\
\hline RM592 & 2.736 .620 & ned & 5 & ATT & 55 \\
\hline OG61 & - & 6-fam & 5 & AG & 56 \\
\hline OSR19 & 1.764 .586 & hex & 6 & CT & 56 \\
\hline RM7309 & 25.914 .707 & ned & 6 & ATTT & 55 \\
\hline RM418 & 18.131 .530 & 6-fam & 7 & ATT & 55 \\
\hline RM336 & 21.818 .658 & hex & 7 & CTT & 55 \\
\hline RM420 & 29.430 .524 & 6-fam & 7 & AAAT & 55 \\
\hline RM481 & - & ned & 7 & CAA & 55 \\
\hline RM6810 & - & hex & 7 & TCT & 50 \\
\hline RM408 & 119.997 & 6-fam & 8 & $\mathrm{CT}$ & 55 \\
\hline RM38 & 2.109 .541 & 6-fam & 8 & GA & 55 \\
\hline RM477 & 28.070 .747 & ned & 8 & AATT & 55 \\
\hline RM105 & 12.496 .528 & ned & 9 & CCT & 55 \\
\hline RM201 & 19.879 .785 & hex & 9 & $\mathrm{CT}$ & 55 \\
\hline OG10 & 2.613 .899 & ned & 9 & $\mathrm{AG}$ & 56 \\
\hline OG106 & - & hex & 9 & $\mathrm{AG}$ & 56 \\
\hline OG45 & - & 6-fam & 9 & AG & 56 \\
\hline RM171 & 18.790 .632 & 6-fam & 10 & GATG & 55 \\
\hline RM222 & 8.173 .931 & 6-fam & 10 & $\mathrm{CT}$ & 55 \\
\hline RM116 & 5.740 .642 & ned & 11 & $\mathrm{CT}$ & 55 \\
\hline RM7283 & 9.024 .217 & hex & 11 & ATCT & 55 \\
\hline RM7226 & 13.936 .515 & hex & 11 & ATAG & 55 \\
\hline RM224 & 26.796.502 & ned & 11 & $(\mathrm{AAG})(\mathrm{AG})$ & 55 \\
\hline RM235 & 26.107 .904 & 6-fam & 12 & $\mathrm{CT}$ & 55 \\
\hline RM415 & - & hex & 12 & AT & 55 \\
\hline RM7504 & - & ned & 4 & TATC & 55 \\
\hline L4 & 6.861 .244 & ned & 6 & ATAG & 60 \\
\hline OG101 & 25.499 .113 & hex & 2 & $\mathrm{AG}$ & 56 \\
\hline
\end{tabular}

${ }^{(1)}$ Reference map of cultivar Nipponbare. ${ }^{(2)}$ Not available. 
considered a reference in molecular studies of rice, was used in all gel electrophoresis as control. In addition, there was an internal control of the fragment size on each lane, which is described below.

Microsatellite alleles were amplified by PCR using 2 ng of DNA with 2,5 $\mu \mathrm{L}$ of Master mix and $0,5 \mu \mathrm{L}$ of Q-solution of the DNA QIAGEN Multiplexer PCR kit solution, both Master mix and Q-solution (QIAGEN, Düsseldorf, Germany), completing the volume up to $5 \mu \mathrm{L}$ with DNAse-free water. The primer concentrations varied between $0.2 \mu \mathrm{mol} \mathrm{L}^{-1}$ for 6 -Fam and Ned and $0.4 \mu \mathrm{mol} \mathrm{L}^{-1}$ for Hex fluorochrome marked primers. The amplification reactions were carried out in a GeneAmp PCR System 9700 thermocycler (Applied Biosystems, Foster City, USA), using the following program: $94^{\circ} \mathrm{C}$ for $15 \mathrm{~min}, 94^{\circ} \mathrm{C}$ for $30 \mathrm{~s}, 55^{\circ} \mathrm{C}$ for $1 \mathrm{~min}$ and $30 \mathrm{~s}, 72^{\circ} \mathrm{C}$ for $1 \mathrm{~min}$, steps 2,3 and 4 repeated 35 times, and $72^{\circ} \mathrm{C}$ for $30 \mathrm{~min}$. One microliter of the amplified PCR product was then diluted five times in ultrafiltrated water (MilliQ, Millipore, Billerica, USA), and mixed in $8 \mu \mathrm{L}$ of HI-DI with $1 \mu \mathrm{L}$ of an internal fragment size of DNA standard (Brondani \& Grattapaglia, 2001) at the ratio 0.6:0.4 v/v of ultrafiltrated water, followed by denaturation at $95^{\circ} \mathrm{C}$ for $5 \mathrm{~min}$. The PCR products were electroinjected in an automatic DNA sequencer ABI Prism 3700 (Applied Biosystems, Foster City, USA) using the D filter to capture the fluorescence after approximately 2 hours of electrophoresis. The fragments were analyzed and genotyped with the Applied Biosystems GeneScan vers. 3.1.2 and Genotyper vers. 2.5.2 (Applied Biosystems, Foster City, USA) softwares, respectively.
Values of genetic distance in pairwise comparisons between the 26 samples of rice were estimated using the shared allele distance coefficient, which is based on the ratio between the sum of the proportions of the shared alleles between two accessions (Ps) for all of the loci and twice the number of loci tested (Bowcock et al., 1994; Goldstein et al., 1995), followed by the use of the parameter $[(-\ln (\mathrm{Ps})]$ in the application web genetic distance calculator (Brzustowski, 2003). The diagonal matrix of genetic distances was submitted to grouping analysis using the neighbor-joining method, and a dendrogram of genetic distances was constructed using the NTSYSpc version 2.10z program (Rohlf, 2002). The estimates of genetic conversion were calculated by the proportion of alleles from the mutant donor line 93AS3510 which were retained in each of the new imidazolinone-tolerant lines, based on the analysis of 44 microsatellite loci distributed in the 12 chromosomes of the species. The alleles from the mutant line retained in the region of the ALS gene on rice chromosome 2 (Kadaru et al., 2008) were disregarded from the analysis due to the positive selection for this region in each generation of backcrossing $\left(\mathrm{RC}_{1}\right.$ to $\left.\mathrm{RC}_{3}\right)$, and subsequent selfing, which was also submitted to positive selection.

\section{Results and Discussion}

Grain yield of the new imidazolinone tolerant lines, derived from 'BRS 7 Taim' (CNA10754, CNA10755 and CNA10756) and 'BRS Pelota' (CNA10757, CNA10758 and CNA10759), was greater than $8,000 \mathrm{~kg} \mathrm{ha}^{-1}$ and not

Table 2. Agronomic traits - grain yield means, days to flowering (DF), plant height (PH) and incidence ${ }^{(1)}$ of brown spot (BS) and narrow brown leaf spot (NBLS) - of imidazolinone-tolerant lines and of cultivars evaluated in seven different environments, in the state of Rio Grande do Sul, Brazil ${ }^{(2)}$.

\begin{tabular}{|c|c|c|c|c|c|c|}
\hline \multirow[t]{2}{*}{ Genotype } & \multicolumn{2}{|c|}{ Grain yield $\left(\mathrm{kg} \mathrm{ha}^{-1}\right)$} & \multirow[t]{2}{*}{ DF (days) } & \multirow[t]{2}{*}{$\mathrm{PH}(\mathrm{cm})$} & \multirow[t]{2}{*}{$\mathrm{BS}$} & \multirow[t]{2}{*}{ NBLS } \\
\hline & Noninfested $^{(3)}$ & Infested $^{(4)}$ & & & & \\
\hline BRS 7 Taim & $8,189 a$ & $4,349 b$ & 97 & 89 & 2 & 2 \\
\hline CNA10754 & $8,308 \mathrm{a}$ & $6,891 \mathrm{a}$ & 94 & 87 & 2 & 3 \\
\hline CNA10755 & $8,434 a$ & $7,762 \mathrm{a}$ & 95 & 89 & 1 & 2 \\
\hline CNA10756 & $8,331 \mathrm{a}$ & $7,250 \mathrm{a}$ & 95 & 83 & 2 & 2 \\
\hline BRS Pelota & $8,599 \mathrm{a}$ & $4,844 b$ & 90 & 95 & 2 & 2 \\
\hline CNA10757 & $8,179 \mathrm{a}$ & $6,496 a$ & 93 & 98 & 2 & 1 \\
\hline CNA10758 & $8,693 a$ & $7,129 \mathrm{a}$ & 90 & 95 & 2 & 1 \\
\hline CNA10759 & $8,503 a$ & $6,958 \mathrm{a}$ & 93 & 97 & 2 & 1 \\
\hline IRGA 422 CL & $8,656 a$ & $6,262 a$ & 84 & 90 & 2 & 1 \\
\hline$\overline{\text { Mean }}$ & 8,459 & 6,438 & - & - & - & - \\
\hline $\mathrm{CV}(\%)$ & 15 & 10 & - & - & - & - \\
\hline
\end{tabular}


significantly different from the yield of 'BRS 7 Taim', 'BRS Pelota' and 'IRGA 422' CL (Table 2). However, in the experimental trials done with the same lines in Cachoeira do Sul, RS, in a red rice highly infested area in 2006/2007, the advantage of the imidazolinone-tolerant lines in comparison to their respective recurrent parents became more evident (Table 2). In this case, the new lines presented grain yield significantly greater than cultivars BRS 7 Taim and BRS Pelota. In this environment, the new herbicide-tolerant lines had yield above $6,400 \mathrm{~kg} \mathrm{ha}^{-1}$ while the cultivars BRS 7 Taim and BRS Pelota produced 4,349 $\mathrm{kg} \mathrm{ha}^{-1}$ and 4,844 $\mathrm{kg} \mathrm{ha}^{-1}$, respectively. This clearly demonstrates the importance of using herbicide-tolerant varieties in areas infested with red rice. The yields in the noninfested areas were very similar because the lines are near-isogenic to their respective recurrent parent.

No significant differences were observed between the new lines and the respective recurrent parents 'BRS 7 Taim' and 'BRS Pelota' for plant height and days to flowering (Table 2). The imidazolinone-tolerant lines CNA10754, CNA10755 and CNA10756 derived from cultivar BRS 7 Taim, flowered 95 days after emergency, and had a plant height of about $90 \mathrm{~cm}$, similar to the recurrent parent. However, they flowered later than cultivar IRGA 422 CL, which flowered after 84 days after emergency, and did not show symptoms of brown spot and narrow brown leaf spot. Likewise, the lines CNA10757, CNA10758 and CNA10759, derived from cultivar BRS Pelota, flowered 93 days after emergency, and had a plant height of $95 \mathrm{~cm}$, similar to the recurrent parent. These new herbicide-tolerant lines also had a cycle longer than the cultivar IRGA $422 \mathrm{CL}$ and showed no symptoms of brown spot and narrow brown leaf spot.

The lines and the widely cultivated 'IRGA $422 \mathrm{CL}^{\prime}$ had similar percentual of milled whole grain $(\geq 55 \%)$ and total grain $(\geq 67 \%)$, with amilose content varying from intermediate to high levels (Table 3). After cooking, cultivar and line grains remain loose and non sticky. Furthermore, the lines CNA10754, CNA10755 and CNA10757 had more translucent grains, compared to the ones of the controls.

A total of 44 microsatellite loci were used in the analysis of polymorphism between the cultivar BRS 7 Taim and two of the lines derived from it (CNA10754 and CNA10756). Eight microsatellite loci (RM22, RM7431, RM592, OG61, RM7309, RM336, RM408 and RM38) showed no polymorphism between the mutant 93AS3510 and cultivar BRS 7 Taim. One of the loci (OG101) appears to be heterozygote and has a common allele with the mutant 93 AS3510 and with cultivar BRS 7 Taim. The analysis of the DNA extracted in bulk from the seeds obtained from $\mathrm{RC}_{3} \mathrm{~F}_{5}$ indicated that the CNA10754 line is different from cultivar BRS 7 Taim in two loci only (RM300 and RM475). This represents an index of the observed conversion of $97.67 \%$, after correcting for the effect of positive selection for alleles from the 93AS3510 line in the ALS gene region. The CNA10756 line was different from the BRS 7 Taim cultivar in five loci (RM300, RM263, RM335, RM418 and RM171), which represents an observed conversion index of approximately $91.86 \%$.

Comparing the multiloci genotype of 'BRS Pelota' and mutant 93AS3510, four microsatellite loci (RM22, RM7431, OG61 and RM38) did not show polymorphism. Two of the loci (RM420 and OG101) were heterozygotes and had a common allele shared between the mutant 93AS3510 and 'BRS Pelota'. The analysis of the DNA extracted in bulk from the seeds obtained from $\mathrm{RC}_{3} \mathrm{~F}_{5}$ indicated that CNA10757 differed from 'BRS Pelota' in five loci (RM300, RM422, OG44, RM592 and RM7309). This represents an observed conversion index of approximately $92 \%$,

Table 3. Means of grain quality traits ${ }^{(1)}$ - percentual whole milled grain (WMG), total milled grain (TWG), amilose content (AC), gelatinization temperature (GT), white center (WC), cooking ability (CA) and texture (TX) - of the imidazolinone-tolerant lines and of cultivars evaluated in seven environments in the state of Rio Grande do Sul, Brazil.

\begin{tabular}{lccccccc}
\hline Genotype & WMG (\%) & TMG (\%) & AC (\%) & GT & WC & CA & TX \\
\hline BRS 7 Taim & 61 & 70 & 26 & 3 & 3 & L & H \\
CNA10754 & 63 & 70 & 28 & 3 & 2 & L & H \\
CNA10755 & 63 & 70 & 25 & 5 & 2 & L & H \\
CNA10756 & 61 & 69 & 26 & 3 & 3 & L & H \\
BRS Pelota & 60 & 67 & 27 & 7 & 2 & L & H \\
CNA10757 & 56 & 67 & 27 & 7 & 2 & L & H \\
CNA10758 & 56 & 68 & 27 & 7 & 4 & L & H \\
CNA10759 & 55 & 67 & 28 & 7 & 4 & L & H \\
IRGA 422 CL & 58 & 67 & 27 & 7 & 3 & L & H \\
\hline
\end{tabular}

(1)Amilose content: high, $28 \%$ to $32 \%$; medium, $23 \%$ to $27 \%$; low, $11 \%$ to $22 \%$. Gelatinization temperature: high, grades 2 and 3; medium, grades 4 and 5; low, grades 6 and 7. White center: variation from grades 1 (translucid grain) to 5 (white grain). Cooking ability: L, loose; M, medium; S, sticky. Texture: $\mathrm{H}$, hard; $\mathrm{M}$, medium; $\mathrm{S}$, soft. 
after correcting for the effect of positive selection for alleles from the 93AS3510 line in the ALS gene. The CNA10758 line differed from 'BRS Pelota' in four loci (RM7309, RM420, RM222 and OG101), which represents an observed conversion index of approximately $94.18 \%$, after correcting for the effect of positive selection for alleles from the 93AS3510 line in the ALS gene region.

Pairwise genetic distance analysis between the four new imidazolinone-tolerant lines derived from cultivars BRS 7 Taim (CNA10754 and CNA10756) and BRS Pelota (CNA10757 and CNA 10758), as well as the 22 other accessions from the rice germplasm bank, clustered these new lines, as expected, in the group of accessions from the subspecies indica (Figure 1). Genetic distance estimates also corroborated the great genetic similarity between these lines and their respective parents. Additionally, it was observed that the new lines and the cultivar IRGA 417 belong to distinct groups. IRGA 417 was originally used as recurrent parent to derive cultivar IRGA 422 CL. Thus, the new lines increase the options of new and genetically diverse rice cultivars for cultivation in red rice infested fields.

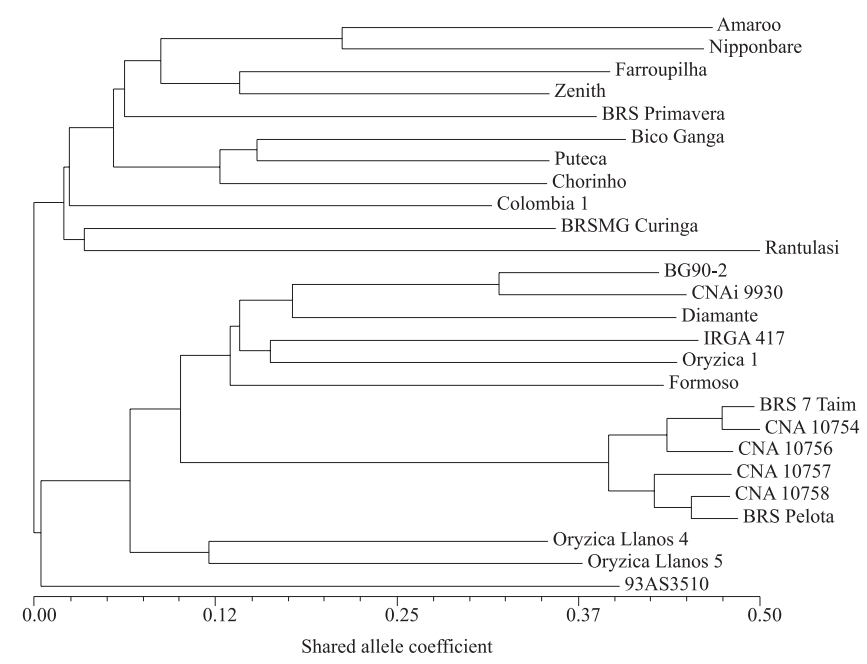

Figure 1. Dendrogram derived from the genetic distance estimates of 26 accessions of the rice subspecies indica and japonica, using the shared allele coefficient grouping analysis, and the neighbor-joining method, including the four new imidazolinone-tolerant lines (CNA 10754, CNA 10756, CNA 10757 e CNA 10758). The analysis of DNA polymorphism between accessions was based on 44 loci of microsatellite markers distributed throughout the rice genome.
After selecting for herbicide-tolerance in each generation of backcrossing, the average percentage of conversion of $\mathrm{RC}_{3}$ plants to the recurrent parent genome is $93.75 \%$. The genotype conversion of the new lines (CNA10754, CNA10756, CNA10757 e CNA 10758) varied from 91.86 to $97.67 \%$, which indicates, as observed when analyzing the agronomic and grain quality phenotypes, that the new imidazolinone-tolerant lines are very similar to their respective parents. The genotypic analysis indicated that the level of residual heterozygosity in the samples tested from each new line varied between 0 and $4.5 \%$ which is considered low.

\section{Conclusions}

1. The new imidazolinone-tolerant irrigated rice lines CNA10756 ('BRS Sinuelo CL') and CNA10757 show phenotypic traits and genotypic profile very similar to their respective recurrent parental cultivars BRS 7 Taim and BRS Pelota and can be released for cultivation in Rio Grande do Sul, Brazil, especially in red rice infested areas.

2. Cluster analysis indicates that the new lines do not group with the current available imidazolinone-tolerant commercial cultivar, increasing the options for new and genetically diverse rice cultivars for cultivation in red rice infested fields.

\section{References}

BOWCOCK, A.M.; RUIZ-LINARES, A.; TOMFOHRDE, J.; MINCH, E.; KIDD, J.R.; CAVALLI-SFORZA, L.L. High resolution of human evolutionary trees with polymorphic microsatellites. Nature, v.368, p.455-457, 1994.

BRONDANI, R.P.V.; GRATTAPAGLIA, D. Cost-effective method to synthesize a fluorescent internal DNA standard for automated fragment sizing. Biotechniques, v.4, p.793-795, 2001.

BRZUSTOWSKI, J. Shared allele distance: individual to individual genetic distance calculator. 2003. Available at: $<$ http:// www2.biology.ualberta.ca/jbrzusto/sharedst.php $>$. Accessed on: 21 July 2010.

COMPANHIA NACIONAL DE ABASTECIMENTO. Acompanhamento da safra brasileira: grãos: safra 2008. Available at: $<$ http://www.conab.gov.br/conabweb $>$. Accessed on: 09 Jan. 2009.

CROUGHAN, T.P.; UTOMO, H.S.; SANDERS, D.H.; BRAVEMAN, M.B. Herbicide-resistant rice offers potential solution to red rice problem. Louisiana Agriculture, v.39, p.10-12, 1996. 
DE BLOCK, M.; BOTTERMAN, J.; VANDEWIELE, M.; DOCKX, J.; THOEN, C.; GOSSELÉ, V.; MOVVA, N.R.; THOMPSON, C.; VAN MONTAGU, M.; LEEMANS J. Engineering herbicide resistance in plants by expression of a detoxifying enzyme. EMBO Journal, v.6, p.2513-2518, 1987.

DOYLE, J.J.; DOYLE, J.L. Isolation of plant DNA from fresh tissue. Focus, v.12, p.13-15, 1990.

DUNNET, C.W. A multiple comparison procedure for comparing several treatments with control. Journal of the American Statistical Association, v.50, p.1096-1121, 1955.

DUNNET, C.W. A new Table for multiple comparisons with control. Biometrics, v.20, p.482-491, 1964.

FERREIRA, M.E; GRATTAPAGLIA, D. Introdução ao uso de marcadores moleculares em análise genética. 2.ed. Brasília: Embrapa-Cenargen, 1996. 220p. (Embrapa-Cenargen. Documentos, 20).

GEALY, D.R.; MITTEN, D.H.; RUTGER, J.N. Gene flow between red rice (Oryza sativa) and herbicide-resistant rice (O. sativa): implications for weed management. Weed Technology, v.17, p.627-645, 2003.

GOLDSTEIN, D.B.; RUIZ-LINARES, A.; CAVALLI-SFORZA, L.L.; FELDMAN, M.W. Genetic absolute dating based on microsatellite and the origin of modern humans. Proceedings of the National Academy of Sciences of the United States of America, v.92, p.6723-6727, 1995.

JENNINGS， P.R.; COFFMAN，W.R.; KAUFFMAN， H.E. Mejoramiento de arroz. Cali: CIAT, 1981. 233p.

KADARU, S.; ZHANG, W.Q.; YADAV, A.; OARD, J.H. Development and application of allele-specific PCR assays for imazethapyr-resistance in rice (Oryza sativa). Euphytica, v.160, p.431-438, 2008.

MALLORY-SMITH, C.A.; RETZINGER JUNIOR, E.J. Revised classification of herbicides by site of action for weed resistance management strategies. Weed Technology, v.17, p.605-617, 2003.

MANUAL de métodos de pesquisa em arroz: primeira aproximação. Goiânia: Embrapa-CNPAF, 1977. 106p.
PESSOA-FILHO, M.; BELÓ, A.; ALCOCHETE, A.A.N.; RANGEL, P.H.N.; FERREIRA, M.E. A set of multiplex panels of microsatellite markers for rapid molecular characterization of rice accessions. BMC Plant Biology, v.7, n.23, 2007. doi:10.1186/1471-2229-7-23.

RANGEL，P.H.N.; GUIMARÃES，E.P.; NEVES，P.C.F. Base genética das cultivares de arroz (Oryza sativa $\mathrm{L}$ ) irrigado do Brasil. Pesquisa Agropecuária Brasileira, v.31, p.349-357, 1996.

ROHLF, F.J. NTSYS-pc: numeric taxonomy and multivariate analysis system. Version 2.1. New York: Exeter Software, 2002.

SAMBROOK, J.; FRITSCH, E.F.; MANIATIS, T. Molecular cloning: laboratory manual. $2^{\text {nd }}$ ed. New York: Cold Spring Harbor, 1989. 694p

SATTERTHWAITE, F.E. An approximate distribution of estimates of variance components. Biometrics Bulletin, v.2, p.110-114, 1946.

SCHMIDT, A.B. Desenvolvimento de painéis multiplex de marcadores microssatélites e mapeamento de QTLs de tolerância à seca e ao frio em linhagens puras recombinantes de arroz (Oryza sativa L.). 2009. 353p. Tese (Doutorado) Universidade Federal de Santa Catarina, Florianópolis.

SOCIEDADE SUL-BRASILEIRA DE ARROZ IRRIGADO. Arroz irrigado: recomendações técnicas da pesquisa para o Sul do Brasil. In: CONGRESSO BRASILEIRO DE ARROZ IRRIGADO, 4.; REUNIÃO DA CULTURA DO ARROZ IRRIGADO, 26., 2005, Santa Maria. Anais. Santa Maria: SOSBAI, 2005. 161p.

TAN, S.Y.; EVANS, R.R.; DAHMER, M.L.; SINGH, B.K.; SHANER, D.L. Imidazolinone-tolerant crops: history, current status and future. Pest Management Science, v.61, p.246-257, 2005.

VAUGHAN, L.K.; OTTIS, B.V.; PRAZAK-HAVEY, A.M.; BORMANS, C.A.; SNELLER, C.; CHANDLER, J.M.; PARK, W.D. Is all red rice found in commercial rice really Oryza sativa? Weed Science, v.49, p.468-476, 2001.

WEBSTER, E.P.; MASSON, J.A. Acetolactate synthase-inhibiting herbicides on imidazolinone-tolerant rice. Weed Sciences, v.49, p.652-657, 2001 .

Received on August 18, 2009 and accepted on June 16, 2010 